\title{
KREATIVITAS SEBAGAI LANDASAN DAN OPERASIONALISASI DALAM PENDIDIKAN MUSIK
}

\author{
Riyan Hidayatullah \\ Prodi Pendidikan Musik FKIP Universitas Lampung \\ riyan.1002@fkip.unila.ac.id
}

\begin{abstract}
Abstrak
Musik merupakan realitas yang terbangun oleh kemampuan berpikir kreatif sehingga menghasilkan karyakarya yang estetis. Dalam konteks pendidikan musik, kegiatan yang dilandasi aktivitas kreatif dan ekspresif juga menjadi aspek yang sangat penting. Artikel ini berusaha menguraikan peran kreativitas dalam pendidikan musik sebagai sebuah landasan berpikir dan operasionalisasinya dalam pendidikan musik. Literatur digunakan untuk mendalami masalah dan menyusun konsep mengenai kreativitas dalam pendidikan musik. Hasil analisis menyebutkan bahwa konsep kreativitas merupakan gagasan yang berpusat pada orisinalitas, berpikir imajinatif, dan berusaha menghasilkan ide atau gagasan baru. Kapasitas kreatif adalah sebuah modal utama dalam mewujudkan tujuan pendidikan musik melalui operasionalisasi konsep-konsep berpikir yang telah disebutkan. Kreativitas dalam pendidikan musik memiliki banyak dimensi seperti historis, sosiologi, ekonomi, politik, psikologi, filosofis, dan religius. Dialektika antar dimensi itu membentuk sebuah ekosistem baru dalam paradigma berpikir pendidikan musik. Kemandirian dan kemerdekaan dalam berpikir merupakan ruh dalam mengembangkan pola berpikir kritis dan kreatif. Orientasi pendidikan musik dapat dikembangkan dalam konteks nilai-nilai yang diinternalisasikan dalam berbagai aspek. Pendidikan musik juga berfungsi sebagai transmisi pengetahuan musik dan menjadikan seseorang terdidik secara musikal. Melalui pengetahuan musik ekosistem musik akan terbentuk sehingga mampu menumbuhkembangkan musik sebagai representasi dari kebudayaan.
\end{abstract}

Kata kunci: berpikir kritis; kreativitas; pendidikan musik

\begin{abstract}
Music is a matter that is set up by the capacity to reflect creatively to generate creative works. In art education, it supports activities on creative and expressive activities are also critical aspects. This article attempts to describe creativity in music education as a basis for thinking and its operation in music education. Literature is used to explore problems and formulate concepts about creativity in music education. The analysis results suggest that the concept of creativity is an idea that is focused on originality, seeing imaginatively, and seeking to provoke new ideas or ideas. Creative capacity is a significant asset in getting the goals of music education by operationalizing the concepts of thought have been discussed. Creativity in music education involves many dimensions: historical, sociological, economic, political, psychological, philosophical, and religious. The inter-dimensional dialectic forms a new ecosystem in the paradigm of thinking in music education. Independence and independence in thinking is the spirit in improving critical and creative thinking patterns. They can develop music education orientation in values which are internalized in various conditions. Music education still operates as an automatic transmission of musical intelligence and makes a person musically educated. Through awareness of music, a music ecosystem will be designed so it can grow music as a cultural image.
\end{abstract}

Keywords: critical thinking; creativity; music education

\section{Pendahuluan}

Terminologi musik selalu hadir di berbagai sektor kehidupan, mulai dari pendidikan, sosial-budaya, hiburan, dan politik. Musik selalu diasosiasikan sebagai bentuk dari 
keindahan atau artefak yang bernilai estetis. Umumnya musik dikaitkan dengan produk artistik seperti komposisi, lagu, soundscape, dan lain-lain. Banyak orang selalu melihat musik sebagai sebuah gagasan yang berbentuk atau berhubungan dengan kebendaan. Dapat didengar dan sangat nyata dampaknya. Belum banyak yang memaknai musik sebagai sebuah sistem informasi, proses sosial, dialek ide-ide besar, dan media untuk menginternalisasikan nilai-nilai budaya secara masif. Musik terdapat di mana saja, baik berwujud ataupun terinternalisasi dalam sebuah pemikiran dan perilaku. Bahkan Khan (2002) menyatakan musik memiliki dimensi mistis, ikut memenuhi kebutuhan rohani. Dengan demikian musik memiliki makna yang luas baik secara fisik maupun mental.

Musik merupakan perwujudan dari seni. Dalam bahasa Inggris seni disebut art yang berarti ekspresi dari kemampuan kreatif dan imajinasi seseorang. Dalam bahasa Jerman seni disebut kunst yang berarti pengetahuan atau keterampilan, sementara dalam bahasa Yunani seni disebut techne yang berarti keterampilan, sistem, atau metode. Di sini sangat jelas bahwa sebenarnya musik sebagai bagian dari seni memiliki hubungan antara pengetahuan, kreativitas, keterampilan, dan teknologi. Musik sebagai sebuah ontologi berangkat dari sebuah pemikiran, menjadi sebuah karya dan lahirlah berbagai metodologi untuk mengkajinya.

Hari ini seni dimunculkan dalam kebijakan-kebijakan yang mengusung nilai-nilai estetis di dalamnya. Program "Merdeka Belajar" yang baru saja diluncurkan oleh Mendikbud adalah salah satunya. Prinsip kemerdekaan adalah landasan utama kreativitas, dan kreativitas adalah roh dari pendidikan seni. Musik sebagai bagian dari seni juga mengandung nilai-nilai estetis yang mendukung kematangan dalam berpikir. Kemerdekaan dalam belajar merupakan langkah awal menuju kemerdekaan dalam berpikir-sebuah prinsip yang terdapat di dalam kreativitas. Modal utama musik adalah mengembangkan kapasitas berpikir kreatif. Jika pendidikan musik diibaratkan sebuah industri besar yang produknya adalah manusia unggul, maka humanisme dalam keleluasaan adalah salah satu trigger-nya.

Pendidikan musik mengandung realisasi nilai-nilai juga masih sangat relevan diwujudkan dalam berbagai elemen kehidupan. Musik tersusun dari elemen seperti melodi, nada, harmoni, dan dinamika. Elemen ini membentuk harmoni yang membentuk musik menjadi indah dan dapat dinikmati. Setiap saat musik hadir selalu membawa kegembiraan bagi para penikmatnya. Harmonisasi adalah landasan yang membentuk musik menjadi 
sesuatu yang estetis. Jika kurikulum disusun berdasarkan paradigma berpikir semacam ini, tentu pendidikan akan menuju arah yang lebih progresif.

Di dalam ekosistem musik dan pendidikan musik hadir berbagai persoalan teknis dan sangat operasional. Inilah yang menyebabkan ekologi musik berjalan sangat lambat. Ketiadaan sinergitas pemerintah dalam memperjuangkan landasan-landasan pendidikan seni menjadi faktor yang paling menentukan. Secara paradigmatis arah kebijakan-kebijakan seni dan pendidikan seni harus berlandaskan konvensi tentang gagasan, riset lintas dan transdisiplin, dan metode budaya. Kreativitas juga harus fleksibel dalam memandang teknologi sebagai sebuah model pemikiran.

Pada titik di mana landasan pendidikan musik dan operasionalisasinya bertemu, harus dibentuk sebuah kesadaran baru yaitu literasi. Selain sebagai proses mental yang baik dan aktivitas budaya, literasi menjadi indikator utama dalam upaya mengampanyekan kreativitas. Literasi dapat dimanifestasikan dalam berbagai bentuk, misalnya literasi dalam berpikir divergen dan konvergen, literasi tentang politik pendidikan musik, literasi tentang membangun komunikasi musikal, dan literasi tentang penerapan elemen-elemen musik dalam kehidupan sehari-hari. Dengan demikian musik menjadi tidak abstrak dan dapat dirasakan manfaatnya secara langsung — masyarakat musik pun ikut merasakan dampaknya. Bagaimanapun, praktik musik dalam pendidikan akan tergantung pada seberapa jauh dukungan pemerintah menanggapinya. Langkah-langkah politis perlu dicanangkan untuk memberi ruang setiap pelaku seni dalam menentukan kebijakan.

Sebagai sebuah studi, seni merupakan konsep yang melandasi pendidikan, bukan hanya sebagai sebuah metode yang berhubungan dengan aspek kepraktisan. Hal ini sejalan dengan pemikiran Herbert Read (1943) tentang seni sebagai sebuah landasan pendidikan yang holistik. Dalam pandangan ini seni merupakan sarana terbaik untuk memperoleh pengetahuan dan keterampilan melalui prinsip-prinsip yang mengedepankan moralitas, kolaborasi, aktualisasi diri, dan kebebasan berekspresi. Inilah perwujudan dari nilai-nilai estetis dalam konteks pendidikan seni. Pemikiran ini mampu dirunutkan dalam konteks pendidikan musik, tentunya dengan mengedepankan nilai-nilai musikal. Ruh pendidikan seni juga dibangun melalui musik sebagai landasan operasionalisasinya. Seluruh elemen musik, mulai dari pelaku musik, guru musik, pembelajar musik, dan pembuat kebijakan mampu bersinergi untuk membentuk sebuah ekosistem musik yang baik dan berlandaskan 
nilai-nilai budaya. Kemitraan dalam ekologi musik menjadi sebuah modal yang kuat untuk terus menumbuhkembangkan pendidikan musik di tengah masyarakat.

Pertanyaan besar yang dapat muncul adalah mengapa musik perlu diajarkan? Mengapa setiap orang perlu belajar musik? Inilah yang menjadi dasar pemikiran penulis tentang pentingnya musik dalam pendidikan. Musik berkenaan dengan aspek rasa, pendidikan yang berbasis musik adalah pendidikan yang mengolah rasa menjadi instrumen dalam menentukan segala hal. Rasa yang menentukan sebuah tindakan dan perilaku. Tanpa melibatkan rasa, nalar, dan logika hanya menjadi realitas yang tidak bermakna (lihat diagram $1)$.

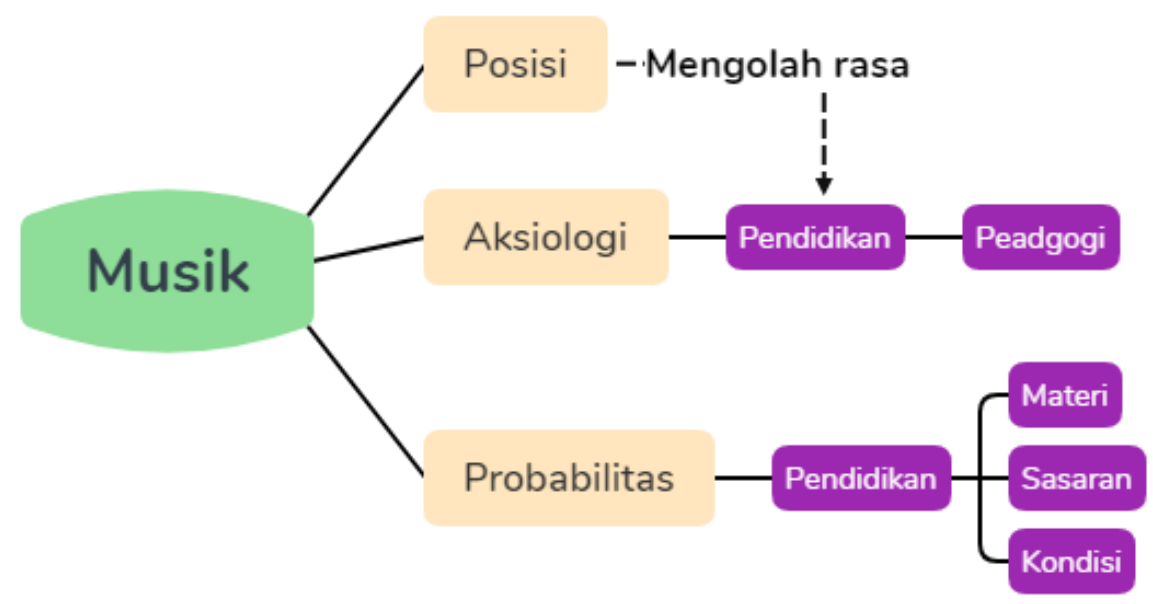

Diagram 1. Pendidikan musik untuk mengolah rasa (Sumber: Hidayatullah)

Aktivitas ekspresif menjadi bagian penting dalam pendidikan musik; sebagai sarana dalam menggugah naluri dan energi positif yang membuat fungsi saraf berkerja dengan baik. Apresiasi dan kreasi adalah langkah yang dapat ditempuh dalam berbagai kegiatan yang berbasis pendidikan. Ini adalah ciri utama dan memberikan penekanan terhadap karakter pendidikan musik. Pendidikan musik yang ideal dibentuk dari sinergitas antara kedisiplinan, material, bentuk, dan fungsi yang ada dalam musik. Musik tidak dapat diapresiasi tanpa sebuah tindakan dan aktivitas, oleh karena itu seni harus dimunculkan untuk dapat dihargai dan dievaluasi. Pendidikan musik harus lebih banyak melibatkan aktivitas fisik yang terpusat pada peserta didik, karena musik merupakan bagian dari konstruksi pengalaman. Musik tidak hanya sekadar dibicarakan, diturunkan, ditularkan, atau diperintahkan melalui lisan, tetapi mengkritisi ide-ide segar yang kemudian menjadi solusi atas sebuah permasalahan. Pada level ini musik menjelma menjadi sebuah metodologi ilmiah yang mampu membuktikan dan menyelesaikan masalah. 
Pendidikan musik adalah salah satu upaya dalam menjawab berbagai persoalan yang terjadi dalam kehidupan sehari-hari. Hal-hal yang bersifat fisik dan metafisik telah banyak dipikirkan. Persoalan selanjutnya adalah bagaimana membangun lingkungan pendidikan yang berbasis musikal. Kreativitas harus bukan sekadar diajarkan atau ditularkan, tetapi tertanam dalam setiap aktivitas pembelajaran sejak dini. Sehingga upaya dalam membentuk generasi yang unggul musikal dapat tercapai.

Musik mampu membahasakan sebuah komunikasi yang kompleks dalam sebuah realitas. Komunikasi dapat dilakukan dengan berbagai cara, diantaranya memberikan perspektif lain atau yang bersifat menginspirasi. Lukisan dengan tema surealisme dapat menggambarkan betapa kompleksnya realitas alam di dunia. Contoh lain, sebuah karya musik kontemporer yang tidak selalu dapat dinikmati. Musik mampu ditempatkan dalam posisi yang abstrak tetapi memiliki dampak yang sangat konkrit. Musik mampu menemukan jalan terbaik dalam menyampaikan pesan. Sesuatu yang mungkin tidak dapat diungkapkan melalui komunikasi verbal. Pablo Picasso menyatakan jika setiap orang terlahir sebagai seniman/artis, permasalahannya adalah bagaimana terus mempertahankannya hingga dewasa. Pernyataan ini berkaitan tentang pengetahuan dan pengalaman yang akan dibangun untuk menghasilkan ide-ide yang artistik dan tetap logis.

Mempelajari musik, melukis, menari, menggambar bukan untuk mendapatkan sebuah penilaian baik atau buruk. Tujuannya adalah memberikan pengalaman estetis dan menggunakan pengalaman tersebut untuk membangun pengetahuan. Konsep atau ide yang terdapat dalam pendidikan musik dapat ditransformasikan menjadi sebuah "cara berpikir musikal" salah satunya melalui kreativitas. Telah banyak penelitian yang menjelaskan bahwa kreativitas adalah inti (core) dari pendidikan musik. Kemudian gagasan ini masih menjadi bias dan belum jelas operasionalisasinya. Jika kreativitas yang menjadi landasan berpikir, tantangannya adalah bagaimana menjadikannya konkrit dan mendapatkan hasil yang nyata.

\section{Kreativitas dalam Pendidikan Musik}

Salah satu landasan utama pendidikan musik adalah kreativitas. Gagasan ini berangkat dari sifat artistik musik yang selalu mencari ide-ide baru, orisinal, fleksibel, multiperspektif, dan imajinatif. Kapasitas kreatif yang dibangun melalui imajinasi menimbulkan kebebasan dalam bepikir dan keberanian untuk mengelaborasikan berbagai 
konsep. Ide-ide mengalir dan bersifat intertekstual dan inspiratif. Melalui kreativitas manusia mampu mengekspresikan perasaannya dalam bentuk yang lebih konkrit. Sebagai sebuah disiplin ilmu, pendidikan musik memberikan keleluasaan tetapi tetap diikat oleh moralitas. Kreativitas membantu seseorang untuk mengeluarkan potensi yang ada dalam diri.

Dalam pendidikan musik, ukuran kebebasan dalam kreativitas adalah keindahan. Keindahan merupakan wujud dari perasaan, sensitivitas, dan keterampilan. Pendidikan musik tidak dipandang dari sudut formal (artefak), tetapi sebuah landasan dalam berpikir dan berperilaku. Pendidikan seni berpusat pada aspek rasa dan diasah melalui interaksi sosial. Jika pendidikan konservatif bersifat imperatif, pendidikan musik memberikan ruang agar peserta didik dapat melatih sikap peduli, berkolaborasi, dan mementingkan nilai-nilai budaya di dalam bertindak.

Telah banyak studi yang mempromosikan kreativitas sebagai landasan dari pendidikan musik. Dalam satu istilah ini saja dapat diturunkan ke dalam beberapa prinsip dasar. Jika kreativitas adalah sebuah pola pikir, maka kemampuan untuk menggali lebih dalam potensi diri adalah ukurannya. Berpikir kreatif setidaknya memiliki keberanian untuk eskplorasi, skeptis, kontradiktif, konstruktif, multi-persepsi, dan menerima semua kemungkinan. Keberanian untuk memikirkan hal-hal tersebut muncul dari sebuah lingkungan yang membebaskan untuk berpikir. Oleh karenanya kreativitas kurang cocok dengan pemikiran yang bersifat konservatif.

Persoalan pendidikan musik saat ini adalah bagaimana menyelesaikan masalahmasalah secara menyeluruh. Cara-cara lama dan konservatif tidak lagi dapat digunakan, tetapi kreativitas dan kesadaran budaya adalah salah satu solusi (lihat Rohidi, 2014). Manusia sebagai subjek harus mampu memaknai nilai-nilai yang dihadapinya (Triyanto, 2014). Pendidikan musik yang baik adalah yang mempertimbangkan aspek perkembangan psikologis siswa. Kegiatan dapat diawali dengan imitasi, dituangkan dalam ekspresi dan mulai menemukan ide-ide baru.

\section{Berpikir Divergen dan Konvergen}

Berdasarkan beberapa hasil studi, kreativitas merupakan penggabungan antara pola berpikir divergen dan konvergen. Konsep berpikir divergen dan konvergen diperkenalkan oleh seorang psikolog asal Amerika J.P. Guilford pada tahun 1956. Divergen berhubungan 
dengan pemikiran yang selalu mencari gagasan-gagasan baru (Tan, Tsubonou, Oie, \& Mito, 2018). Sedangkan berpikir konvergen dikaitkan dengan analisis dan mampu menyelesaikan masalah. Orang yang berpikir divergen memiliki banyak alternatif ide, sedangkan mereka yang berpikir konvergen lebih fokus pada satu jalan penyelesaian. Divergen identik dengan pemikiran konstruktif, konvergen lebih dekat dengan pola positivistik. Secara mekanistis kedua pola pemikiran ini saling terkait dan bersifat komplementer. Ide-ide yang bersifat inovatif pada akhirnya perlu diselesaikan dengan cara-cara ilmiah yang logis. Dalam konteks pendidikan musik, kreativitas - pemikiran divergen dan konvergen-memberikan nilai dan kualitas pembelajaran musik (Hidayatullah, 2020). Jadi pemikiran divergen dan konvergen adalah aspek pembentuk dari kreativitas. Walaupun pemikiran divergen lebih sering dikaitkan dengan kreativitas, pada kenyataannya seni membutuhkan keduanya. Karya musik atau komposisi dengan tingkat presisi dan kompleksitas yang tinggi justru membutuhkan kemampuan berpikir logis, analitis, detail, sistematik, dan evaluatif. Semua itu merupakan komponen berpikir konvergen. Jika divergen diadopsi ke dalam sebuah cara bepikir dalam pendidikan musik, maka konvergen adalah langkah-langkah untuk menyelesaikannya (lihat gambar 1).

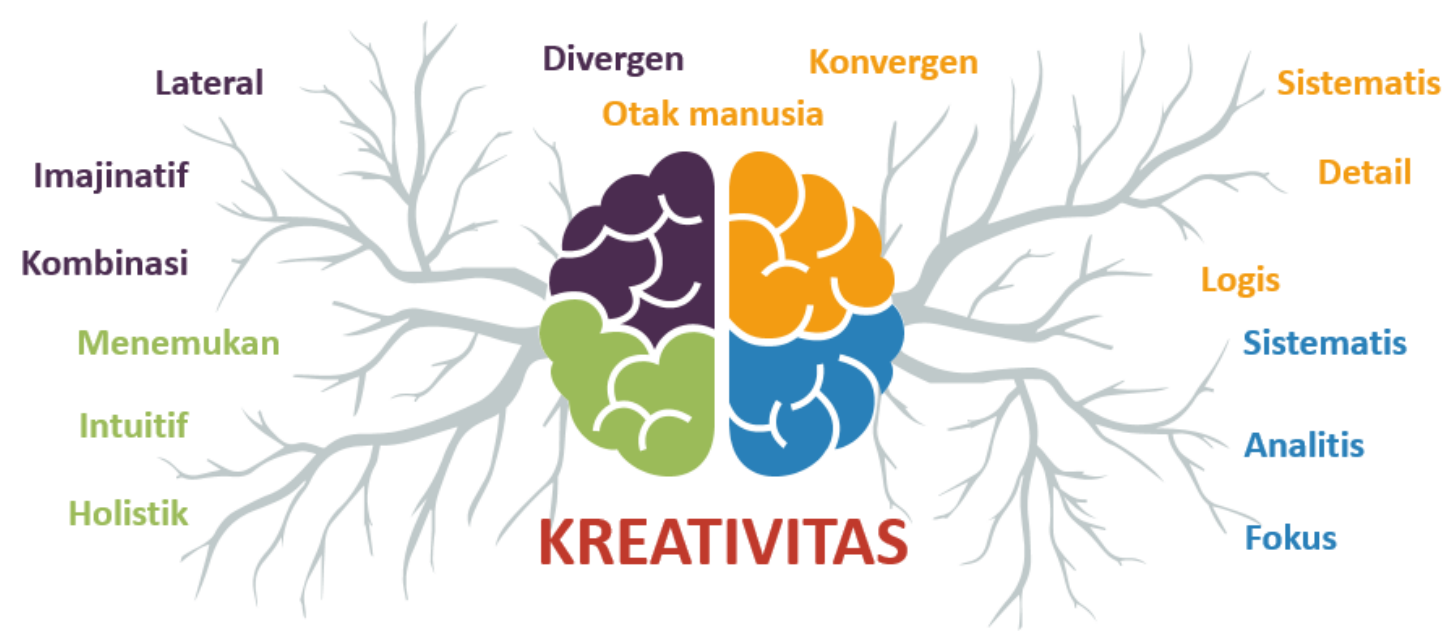

Gambar 1. Kreativitas: pemikiran divergen dan konvergen

(Sumber: Hidayatullah)

Pengalaman estetis mengarah pada pembentukan pola berpikir kreatif. Ini dilandasi oleh peran pemikiran divergen yang selalu mencari berbagai jalan keluar dan konvergen yang menguraikan langkah-langkah pemecahan menuju kepada sebuah solusi. Pengalaman musikal yang dialami seseorang tentu berbeda-beda. Ini dipengaruhi oleh kualitas pembelajaran dalam membentuk cara berpikir divergen dan konvergen. Pendidikan musik 
bertugas untuk menyesuaikan penerapan pola berpikir ini pada masing-masing kapasitas peserta didik. Pemetaan kemampuan adalah bagian penting dalam upaya untuk menumbuhkembangkan cara berpikir kreatif. Seorang pendidik atau guru musik harus mengetahui kemampuan masing-masing siswanya, terutama siswa dengan kreativitas yang baik (lihat Madeja, 1967). Dalam konteks yang lebih luas, orang tua dan guru-guru perlu mengetahui sembilan tipe kecerdasan yang dimiliki oleh anak-anaknya (lihat Gardner, 1999). Dengan memahami prinsip kerja otak dan kemampuan siswa, guru-guru akan dapat menentukan pendekatan yang cocok bagi masing-masing anak. Musik sebagai alat juga dapat digunakan untuk memunculkan gairah dalam belajar (Ritter \& Ferguson, 2017). Pada kondisi tertentu, guru perlu memanfaatkan musik sebagai media untuk menumbuhkan minat dan motivasi dalam belajar.

\section{Operasionalisasi Kreativitas dalam Pendidikan Musik}

Persoalan makro pendidikan musik terkait dengan berbagai komponen yang sangat luas, mulai dari masukan (input), proses, dan luaran (output). Masukan meliputi sistem nilai, pengetahuan, sumber daya manusia, media, sarana, dan lain-lain. Proses berhubungan dengan segala aktivitas dan pengaturan di dalamnya. Luaran berupa pengetahuan musik, keterampilan musik, dan sikap yang dipengaruhi dari kreativitas. Selama ini, sinergitas antara komponen-komponen ini terasa belum kuat dan terkesan berjalan sendiri-sendiri. Belum rampung menghadapi masalah pendidikan, musik memiliki akses terbatas untuk masuk dalam sebuah sistem yang integral dan kuat. Aktivitas digital dapat menjadi modal yang kuat untuk mengembangkan konsep pembelajaran jarak jauh saat ini. Belajar instrumen musik melalui video daring dapat menjadi salah satu pilihan bagi guru musik (King, Prior, \& Waddington-Jones, 2019).

Sebagaimana sebuah bisnis, musik juga melakukan upaya kreatif dalam rangka meningkatkan dan memperluas dampaknya. Hal ini berkaitan dengan arah politik pendidikan musik di masa depan. Apakah musik akan masuk ke wilayah kebijakan dalam bentuk peraturan perundang-undangan, atau hanya sekadar bagian kecil dari program-program pemerintah pusat dan daerah. Upaya-upaya kreatif perlu diwujudkan dalam rangka mengawal pendidikan musik lebih disadari, dihargai, diadopsi, dan disosialisasikan secara merata dan radikal. Musik harus mengakar dan terinternalisasi dalam seluruh aspek kehidupan-menjadikannya sebuah "hukum yang mengikat". Pada akhirnya musik dan 
pendidikan musik akan tumbuh subur dan mencari pola-pola baru dalam membelajarkan manusia.

Membangun kapasitas kreatif tentu tidak hanya dilakukan oleh guru atau siswa, keduanya harus bersinergi. Tetapi secara operasional masing-masing memiliki tahapan yang berbeda dalam tindakanya. Misalnya seorang guru bertugas untuk mempertemukan siswa dengan pengalaman estetis. Salah satu caranya adalah dengan melibatkan siswa dalam kegiatan-kegiatan seni di luar kelas yang bersifat informal. Melalui pengalaman seni, siswa belajar musik secara tekstual dan kontekstual. Lembaga pendidikan dan lembaga budaya saling bekerja sama untuk menciptakan sinergitas dalam rangka mengembangkan kapasitas kreatif.

Melalui aktivitas menggambar siswa belajar banyak hal. Misalnya ketika salah seorang anak menyaksikan hasil karya teman-temannya yang sangat berbeda, ini mengajarkan konsep pendidikan multikultural (lihat Banks \& Banks, 2009). Selain itu, keberanian untuk melakukan eksplorasi dalam gambarnya adalah sesuatu yang sangat penting. Guru tidak menilai baik atau buruk hasil karyanya, tetapi cerita di balik gambar tersebut. Ini adalah awal siswa diperkenalkan pada aspek ekstraestetik dari sebuah karya seni. Gagasan dan orisinalitas merupakan hal yang utama. Melalui karakter dan moralitas diharapkan mampu menjadi penyeimbang intelektualitas seseorang (Sambira \& Kristanto, 2020). Pengalaman itu akan memberikan dampak yang besar di masa depan. Jika kelak seorang anak menjadi penulis, maka prinsip-prinsip tersebut mampu diinternalisasikan dalam buku atau makalahnya, misalnya menghindari plagiarisme. Contoh lain misalnya musik tidak selalu digunakan untuk mengajarkan seorang anak untuk terampil bermain musik, tetapi melalui musik siswa mampu mengembangkan kapasitas kreatifnya. Banyak kegiatan yang dapat dilakukan di dalam atau di luar kelas, pada titik ini peran guru musik dan kreativitasnya sangat berperan.

Kreativitas dalam pendidikan musik berfungsi sebagai frame bagi aktivitas musikal selanjutnya. Dengan kreativitas, arah pendidikan musik terikat oleh batasan-batasan etis, logis, dan estetis. Ketiga batasan tersebut diturunkan dalam sebuah landasan berpikir sebagi berikut.

1) Landasan historis

Landasan ini memberikan orientasi berpikir terhadap pengalaman di masa lalu. Siswa yang terlibat dalam sebuah pengalaman estetis lebih memiliki potensi untuk bertindak 
secara kreatif — karena nilai ini telah dijadikan sebagai titik tolak dalam berpikir dan berperilaku.

2) Sosiologis

Kerangka sosio-budaya dalam pendidikan musik terbentuk dari interaksi seseorang dengan lingkungannya. Apakah interaksi tersebut menyebabkan cara berpikir dan kesadaran tertentu. Pendidikan musik memosisikan diri sebagai fasilitator yang mengakomodasi segala kebutuhan tentang nilai-nilai kearifan lokal. Banyak musik yang dapat digunakan sebagai upaya menumbuhkan kesadaran identitas daerahnya.

3) Ekonomi

Salah satu tujuan akhir dari sebuah pengembangan kreativitas adalah aspek ekonomi. Melalui ekonomi, eksistensi musik dapat terus berlangsung dan terjaga ekologinya. Berpikir kreatif tidak lagi sekadar menyalurkan ide, tetapi bagaimana ide tersebut dapat dijual dan dihargai. Musik harus dapat meningkatkan kualitas hidup secara ekonomi maupun sosial bagi para pelakunya. Selain itu, sebagai sebuah ide \& gagasan, seni dapat memiliki daya jual yang tinggi di tingkat internasional. Berbagai ide kreatif dan gagasan tersebut dapat disalurkan melalui badan-badan dan kementrian negara agar mudah diimplementasikan secara masif. Selanjutnya para pelaku musik akan semakin bersemangat menyalurkan ide-ide besarnya, karena mereka merasakan dampaknya baik secara langsung dan tidak langsung. Akhirnya musik menjadi ikon nasional, menciptakan berbagai lapangan usaha baru yang sebelumnya tidak pernah ada, dan ikut memajukan warisan budaya dan nilai lokal.

4) Politik

Kreativitas dalam pendidikan musik harus mengarah pada suatu ideologi yang menjadi sebuah dasar cita-cita. Dalam konteks pendidikan musik di sekolah misalnya, prestasi belajar dapat menjadi salah satu cara untuk mengambil peran. Siswa berprestasi umumnya mendapat ruang lebih dalam hal bertindak dan menentukan permainan. Strategi-strategi kreatif dapat dimunculkan dengan tujuan "politis” dalam konteks kelas.

5) Psikologis

Kreativitas hidup di dalam pemikiran seseorang, dan ini sangat berkenaan dengan faktor psikologi. Melalui psikologi kreativitas dapat diukur dan dicari apa yang menyebabkan seseorang kurang termotivasi dalam belajar. 
6) Filosofis

Prinsip kreativitas sesungguhnya adalah mendorong siswa untuk terus berpikir, bertanya, menggali informasi, dan mencari ide-ide baru. Hal-hal tersebut merupakan roh dari pemikiran filosofis, karena filsuf selalu berupaya untuk mencari sebuah jalan kebenaran.

7) Religius

Aturan-aturan agama diterjemahkan sebagai sebuah kebaikan. Segala bentuk perilaku yang mengandung nilai kebaikan menjadi terlihat estetis. Untuk itu kreativitas berupaya untuk mencari hal-hal baru yang memenuhi unsur-unsur tersebut. Kreativitas adalah tindakan yang menimbulkan perilaku estetis, dalam musik nilai-nilai kedisiplinan, kolaborasi, dan harmoni menjadi modal kuat untuk menanamkan karakter. Pembentukan karakter yang baik tentu sejalan dengan nilai-nilai agama.

Kegiatan inti dari pendidikan musik adalah membangun kreativitas pada diri seseorang. Operasionalisasinya harus mendukung kepada tujuan yang mengarah kepada pembentukan kapasitas itu. Bagaimana mengolah kemampuan berpikir kritis dan kreatif melalui pola berpikir divergen dan konvergen adalah salah satu tahapan awalnya. Fungsifungsi utama pendidikan musik harus diturunkan menjadi rencana-rencana strategis dalam pembelajaran. Dalam hal pengelolaan sumber daya manusia-guru misalnya-fokusnya bukan hanya pada kompetensi keterampilan bermusik, tetapi pada aspek-aspek pengetahuan dan pedagogis yang kuat. Seorang pendidik musik yang memiliki kompetensi yang lengkap, akan mampu mengarahkan peserta didik pada sebuah desain pembelajaran musik yang ideal. Dalam pembelajaran jarak jauh saat ini, pendidikan musik menghadapi tantangan yang besar karena berhubungan dengan aspek praktis. Gaya belajar menjadi salah satu kunci dalam menentukan keberhasilan pembelajaran jarak jauh (Costa, Souza, Valentim, \& Castro, 2020).

Fungsi operasional pendidikan musik harus dapat mengatur dan menempatkan potensi-potensi musik sesuai kapasitasnya. Guru dengan kapasitasnya dan murid dengan kapasitasnya, semuanya itu membentuk sebuah siklus yang saling fungsional. Jika menggunakan analogi sebuah perusahaan, maka mengelola karyawan, proses produksi, dan pemasaran adalah komponen-komponen utama. Karyawan adalah pendidik musik itu sendiri, proses produksi berkaitan dengan tugas-tugas pokok, merumuskan materi ajar musik, menguji kualitas materi ajar musik, dan selalu melakukan perawatan (maintenance) 
terhadap subjek-subjek pendidikan musik. Terakhir adalah pemasaran, para pelaku atau pendidik musik harus memastikan bagaimana unsur kreativitas terserap dengan baik oleh peserta didiknya. Selain itu bagaimana komponen-komponen dalam pendidikan musik mampu diadopsi dan digunakan sebagai sebuah model pendidikan yang kokoh. Dalam konteks pendidikan musik, ada hubungan yang kuat antara kreativitas, kolaborasi, dan masa depan seseorang (Creech, Larouche, Generale, \& Fortier, 2020).

Di balik sebuah kematangan musikal yang terlihat indah, ada upaya-upaya teknis yang dikerjakan untuk menciptakan kondisi ideal dari pendidikan musik. Jika kreativitas yang menjadi landasan utama pendidikan musik, maka setiap problem yang ada dalam pelaksanaannya harus terselesaikan. Secara umum operasionalisasi pendidikan musik ditentukan oleh lingkungan, kompetensi subjek, dan mental.

Secara sosiologis manusia dan karya musik merupakan struktur yang saling terkait. Pendidikan musik harus melihat lanskap musik dalam bentuk yang lengkap, baik sebagai penikmat, pengkaji, peneliti, pendidik, atau kurator. Pelaku musik dan masyarakat umum akan selalu bersentuhan. Interaksi yang terjadi harus mampu menciptakan harmoni, pelaku musik dan penikmat musik harus saling menyesuaikan. Riset merupakan salah satu upaya untuk mengembangkan pengetahuan objektif mengenai gejala sosial masyarakat. Apakah musik selalu dalam keadaan baik, atau sebaliknya timbul banyak konflik yang menyebabkan paradigma-paradigma baru muncul untuk menyelesaikannya. Dalam pandangan psikologi, apakah para pelaku musik telah benar-benar tercukupi kebutuhannya. Motivasi dan minat dalam berkarya ditentukan oleh tingkat kesejahteraan senimannya. Jika masyarakat musik belum tercukupi kebutuhannya maka sulit untuk menciptakan sebuah aktualisasi diri dalam konteks kreativitas. Kreativitas hanya mampu dibangun dalam kondisi-kondisi yang telah mapan (lihat Maslow, 1954).

Selanjutnya dalam hal komunikasi, masyarakat harus berupaya untuk mengubah cara pandang atau persepsi tentang musik. Langkah ini dilakukan dengan mediasi yang melibatkan unsur seniman, penikmat, pemerintah, dan pemilik modal. Prinsip dasar komunikasi belum benar-benar diterapkan yakni ada pengirim pesan, ada pesan, dan penerima pesan. Selama ini seniman hanya fokus mengirimkan pesan lewat karya, tetapi belum ditangkap maksudnya oleh penerima pesan, apakah ini ditujukan untuk pemerintah atau pihak terkait, sehingga tidak adanya hubungan timbal balik. Komunikasi terjadi hanya satu arah, begitupun pemerintah, sibuk memasang sinyal untuk menerima ide-ide kreatif tetapi gagasan-gagasan itu adanya di lapangan, tidak semua mau turun dan menelusuri apa 
sebenarnya dan bagaimana kompleksnya. Seniman, pemerintah, dan akademisi harus menjalin hubungan yang baik dalam membentuk ekologi musik yang mapan (lihat diagram 2).

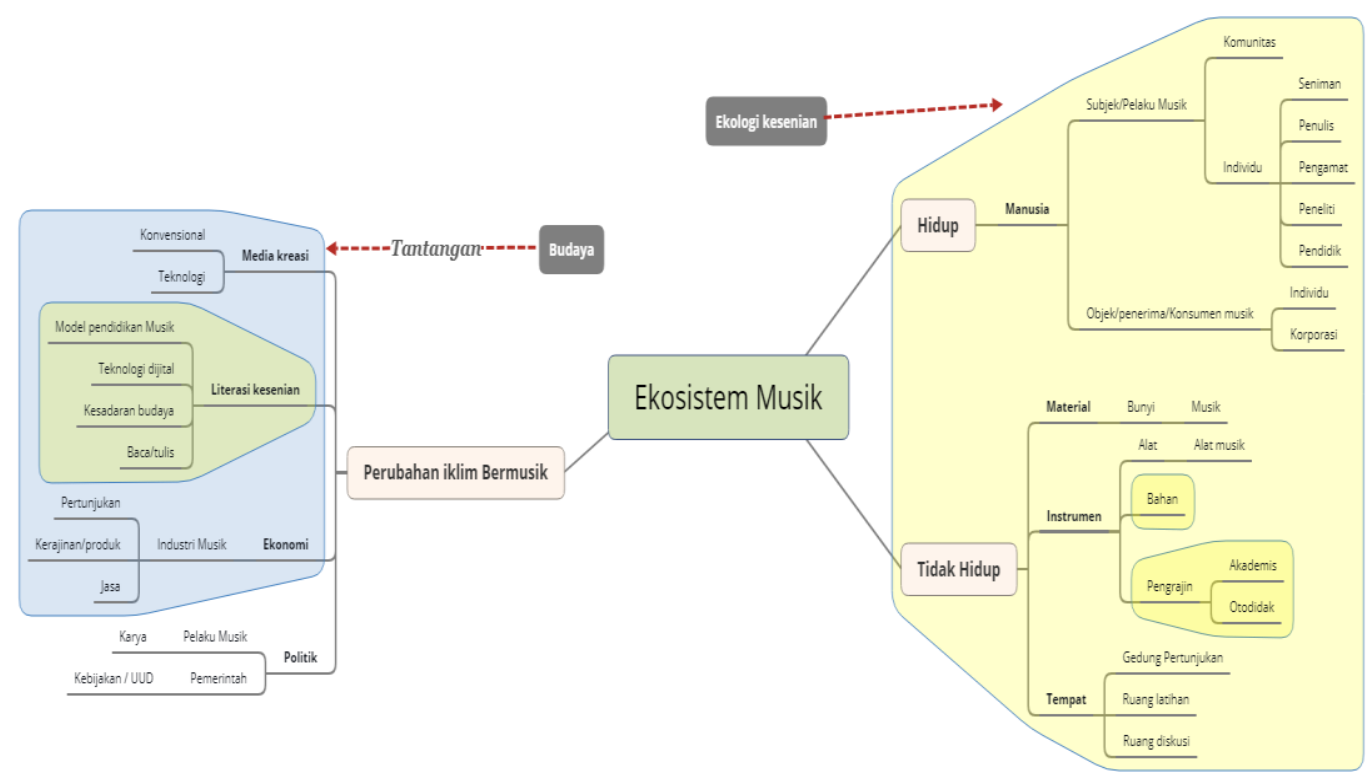

Diagram 2. Ekosistem dan ekologi musik

(Sumber: pemikiran penulis)

Masyarakat sebagai sebuah makhluk budaya memiliki persepsi dan pengalaman yang berbeda. Hal ini juga berpengaruh terhadap cara pandang mereka dalam memandang musik. Banyak produk-produk musik yang mungkin belum ditemukan atau disadari sebagai sebuah konsep yang penting dalam pendidikan musik. Dalam pandangan sosiologis, paradigma ini dapat dilihat sebagai sebuah dialektika di mana manusia harus bergerak ke arah pola pemikiran budaya. Pemikiran atau kesadaran budaya akan menuntun seseorang memikirkan keberlanjutan dari musik, apa tujuannya, dan bagaimana cara untuk melakukannya. Pola pikir ini juga menuntut untuk melihat berbagai persoalan dari berbagai sudut pandang atau perspektif baru. Setiap pemikiran, baik untuk saat ini atau belum terlihat baik harus tetap dipertimbangkan sebagai dasar dalam melakukan sebuah keputusan. Semakin banyak sudut pandang yang terbentuk, maka hasilnya akan semakin baik. Inilah tujuan dialektika yakni mencapai sebuah gambaran kompleks yang akan berguna di masa depan. Kapasitas kreatif mampu membaca dialektika yang terjadi dengan baik. Dengan demikian kreativitas sebagai roh dari pendidikan seni mampu dimaksimalkan karena merupakan hasil sintesis berbagai sudut pandang. 


\section{Kesimpulan}

Kreativitas adalah modalitas utama dalam membentuk karakter seseorang melalui pendidikan. Dengan menanamkan konsep ini dalam seluruh wilayah pendidikan maka dapat menghasilkan generasi-generasi yang mampu berpikir maju. Di era perkembangan teknologi yang sangat maju seperti sekarang ini, pemikiran kreatif semakin dibutuhkan untuk menjawab tantangan zaman. Bekerja tidak lagi dipandang sebagai aktivitas harian yang harus dilakukan di kantor, tetapi di mana saja. Pemikiran yang berlandaskan kreativitas akan selalu menemukan inovasi. Banyak jenis pekerjaan baru muncul yang ide awalnya lahir dari sebuah pemikiran kreatif. Musik adalah sebuah ontologi yang bersifat estetis, jika pendidikan dilandasi pola pemikiran estetis maka level ketercapaian tujuan pendidikan lebih terarah.

\section{Kepustakaan}

Banks, J. A., \& Banks, C. A. M. (2009). Multicultural education: Issues and perspectives (7th ed.). United States of America: John Wiley \& Sons.

Costa, R. D., Souza, G. F., Valentim, R. A. M., \& Castro, T. B. (2020). The theory of learning styles applied to distance learning. Cognitive Systems Research, 64, 134145. Retrieved from https://doi.org/10.1016/j.cogsys.2020.08.004

Creech, A., Larouche, K., Generale, M., \& Fortier, D. (2020). Creativity, music, and quality of later life: A systematic review. Psychology of Music, 0305735620948114. Retrieved from https://doi.org/10.1177/0305735620948114

Gardner, H. (1999). Intelligence reframed: multiple intelligences for the 21 st century. New York, NY: Basic Books.

Hidayatullah, R. (2020). Kreativitas dalam pendidikan musik. Musikolastika: Jurnal Pertunjukan Dan Pendidikan Musik, 2(1), 1-7. Retrieved from https://doi.org/doi: 10.24036/musikolastika.v2i1.32

Khan, H. I. (2002). Dimensi mistik musik dan bunyi (The mysticism of sound and music). Yogyakarta: Pustaka Sufi.

King, A., Prior, H., \& Waddington-Jones, C. (2019). Exploring teachers' and pupils' behaviour in online and face-to-face instrumental lessons. Music Education Research, 21(2), 197-209. Retrieved from https://doi.org/10.1080/14613808.2019.1585791

Madeja, S. S. (1967). The effects of divergent and convergent emphasis in art instruction on students of high and low ability. Studies in Art Education, 8(2), 10-20. Retrieved from https://doi.org/10.2307/1320033

Maslow, A. H. (1954). Motivation and personality. United States of America: Harper \& Row,Publishers, Inc.

Read, H. (1943). Education through art. United States of America: Faber and Faber. 
Ritter, S. M., \& Ferguson, S. (2017). Happy creativity: Listening to happy music facilitates divergent thinking. PLOS ONE, 12(9), e0182210. Retrieved from https://doi.org/10.1371/journal.pone.0182210

Rohidi, T. R. (2014). Pendidikan seni: Isu dan paradigma. Semarang: Cipta Prima Nusantara Semarang.

Sambira, Z., \& Kristanto, A. (2020). Paradigma pendidikan seni berbasis karakter dalam musik ma'badong. Tonika: Jurnal Penelitian Dan Pengkajian Seni, 3(1), 15-26. Retrieved from https://doi.org/10.37368/tonika.v3i1.128

Tan, A.-G., Tsubonou, Y., Oie, M., \& Mito, H. (2018). Creativity and music education: A state of art reflection. In Y. Tsubonou, A.-G. Tan, \& M. Oie (Eds.), Creativity in music education (pp. 3-16). New York, NY: Springer Berlin Heidelberg.

Triyanto. (2014). Pendidikan seni berbasis budaya. Jurnal Imajinasi, 7(1), 33-42. 